\title{
Muakhi culture as ethnic conflict management in Lampung
}

\section{Budaya muakhi sebagai manajemen konflik etnis di Lampung}

\author{
Luthfi Salim ${ }^{\bowtie}$ \& Idrus Ruslan ${ }^{2}$ \\ ${ }^{1}$ Department of Sociology, Faculty of Social and Political Sciences, Universitas Airlangga \\ Surabaya, 60286, East Java Province, Indonesia \\ ${ }^{2}$ Departement of Religious Studies, Faculty of Ushuluddin and Religious Studies, \\ UIN Raden Intan Lampung \\ Bandar Lampung, 35131, Lampung Province, Indonesia \\ E-mail of corresponding author: luthfisalim51@gmail.com
}

\begin{abstract}
The transmigration program forms Lampung society to be multicultural that easily triggers the emergence of ethnic conflicts. In Lampung, it has unexpectedly formed enclaves that cause migrants and local people to not be integrated so that there is polarization and an economic gap between migrants and local people. This is because the economy of migrants advances which causes social jealousy. This study aimed to explain muakhi as conflict management from pre-conflict to post-conflict. This study was qualitative research with phenomenology and multiple case approaches. The research data were obtained by in-depth interviews. The results of this study are first, muakhi in pre-conflict management is managed by the traditional leaders to conduct deliberation and agreement. Second, muakhi in post-conflict management is managed and controlled by all elements of the community. The village officers, traditional leaders, religious leaders, community leaders, or mass organizations remind each other by means of cooperation with the conflicting parties. This study concluded that muakhi is able to create social and media integration and a forum for creating peace in accordance with the values and norms in the lives of the community.
\end{abstract}

Keywords: conflict management; ethnic conflict; muakhi; transmigration

\begin{abstract}
Abstrak
Program transmigrasi membentuk masyarakat Lampung multikultural yang memudahkan timbulnya konflik etnis. Program transmigrasi di Lampung tidak disadari telah membentuk kantong-kantong yang menyebabkan pendatang dan pribumi tidak terintergrasi sehingga terjadi polarisasi dan gap ekonomi antara pendatang dan pribumi. Hal ini disebabkan ekonomi pendatanng lebih dulu maju yang menyebabkan kecemburuan sosial. Studi ini bertujuan untuk menjelaskan muakhi sebagai manajemen konflik dari pra-konflik hingga pasca-konflik. Studi ini menggunakan penelitian kualitatif pendekatan fenomenologi dan multiple case. Data studi ini didapatkan dengan wawancara mendalam. Hasil studi ini menunjukkan bahwa, pertama, muakhi dalam manajemen pra-konflik dikelola oleh tokoh adatnya untuk melakukan musyawarah dan perjanjian. Kedua, muakhi dalam manajemen pasca-konflik dikelola dan dikontrol oleh semua elemen masyarakat. Aparat desa, tokoh adat, tokoh agama, tokoh masyarakat, ataupun ormas saling mengingatkan dengan cara kerjasama antarpihak yang berkonflik. Studi ini menyimpulkan bahwa muakhi mampu menciptakan integrasi sosial dan media serta wadah dalam menciptakan perdamaian yang sesuai dengan nilai dan norma dalam kehidupan masyarakat.
\end{abstract}

Kata Kunci: manajemen konflik; konflik etnis; muakhi; transmigrasi

\section{Introduction}

Ethnic conflict in Lampung is developed from the transmigration program which made Lampung society multicultural and caused social inequality. This ethnic conflict makes the local people and migrants not integrated properly, resulting in polarization and economic disparities between the local people and migrants because the economy of migrants advances compared to that of the local people (Budianto 2020). The Lampung ethnic community has a friendly principle and is open to migrants. In their local terms, this attitude is called nemui nyimah, which is an expression of the principle of kinship to create an attitude of intimacy and harmony as well as mutual friendship (Nurdin 2017). 
Historically, the Dutch East Indies Government established a transmigration program due to high population growth on Java Island which was not accompanied by the provision of jobs, causing poverty and population density (Pratiwi \& Insani 2019). Transmigration in the colonial era had three programs to improve the welfare of the migrant community by means of education, irrigation, and emigration. Migrant residents were provided with education in farming, farming methods, and irrigation facilities. The transmigration program was carried out to improve the lives of migrant residents to be more prosperous. Migrants were given the freedom in naming the regions. This was carried out so that the migrants felt the ownership and love of their new area like their original village. (Khoiriyah et al. 2019).

Prior to the implementation of the transmigration program, the Dutch East Indies government had already made contact with the local people. The Dutch East Indies Government approached them by visiting the traditional heads (punyimbang adat) of the local people. The approach was taken to obtain permission from the traditional head (punyimbang adat) to carry out the transmigration program by deliberation. After getting an agreement between the two parties, the traditional heads handed over the land to the Dutch East Indies Government by arranging a traditional ceremony. The formation of muakhi was by tying the brotherhood with a traditional ceremony called angkon muakhi. This traditional ceremony was carried out to raise the Dutch East Indies Government to be a brother to the people of Lampung. After the procession of the angkon muakhi ceremony was carried out, the Dutch East Indies Government was entitled to land for transmigration residents. The Dutch East Indies Government immediately took measurements of land for gardening and farming, without involving the traditional heads (punyimbang adat) which in the end led to ethnic conflicts until now.

The Dutch East Indies Government provided the transmigrants land to farm. Each head of the family of the transmigrant residents got 70 hectares of rice fields and 30 hectares of garden areas. The transmigrant residents also received life insurance such as health facilities, farming equipment, and building materials from the Dutch East Indies Government. These facilities were provided so that the transmigrant residents felt at home and could encourage their relatives to participate in the transmigration program. After the first transmigration program was successful, the transmigrants brought their relatives to join the next transmigration program. This transmigration program was successfully applied, resulting in thousands of Javanese moving to the Lampung area (Andria 2019).

Principally, Lampung society is a cultured society because they have a symbol and identity as a guide in shaping the behavior of the lives of the community. Lampung society has a tradition of acting or speaking according to local wisdom. The local wisdom of the Lampung society is called piil pesenggiri which has five elements, one of which is nemui nyimah which means a form of expression of the principle of kinship in an attitude of intimacy and harmony (Syahputra \& Ruslan 2021). The Lampung society has guidelines in life as a guide, so that their lives have boundaries and directions in living social life (Minandar 2019).

Lampung is a multicultural area because it has various ethnic groups, cultures, tribes, languages, religions, and customs, all of which are formed from the transmigration program. The multicultural society in Lampung has formed a harmonious co-existence, free to adhere to beliefs, languages, and traditions developed (Sinaga 2017). This multicultural society in Lampung is inherent because the transmigration program has shaped the Lampung area into territories or created unintegrated enclaves between the local people and the migrants which trigger the emergence of horizontal conflicts (Irham 2013).

Ethnic conflicts in Lampung arise in border areas between tribes because the nature of Lampung society still prioritizes their communal ego which has become their inherent nature. The lives of the Lampung society are still in groups or still prioritize ethnicity, either between Lampung ethnicity and Lampung, Javanese, Sundanese, Balinese, Minang, Batak, and so on. This matter causes the emergence of horizontal conflicts due to the low level of cultural acculturation (Syufa'at et al. 2017). 
Lampung has local wisdom in overcoming inter-ethnic conflicts, which is muakhi, which aims to create the value of brotherhood in realizing the form of inter-ethnic relations with the form of peace. Muakhi is a brotherhood, either brotherhood in the family, neighborly relations, and inter-ethnic relations (Hartoyo 2019). The formation of muakhi contains values that are shared between ethnic groups and are actualized in a social form to create peace (Singagerda et al. 2020). The condition for the formation of muakhi is by binding the brotherhood which begins with a traditional ceremony process called angkon muakhi. The steps of the process of angkon muakhi as a traditional ceremony in the appointment of brotherhood is illustrated in Figure 1.

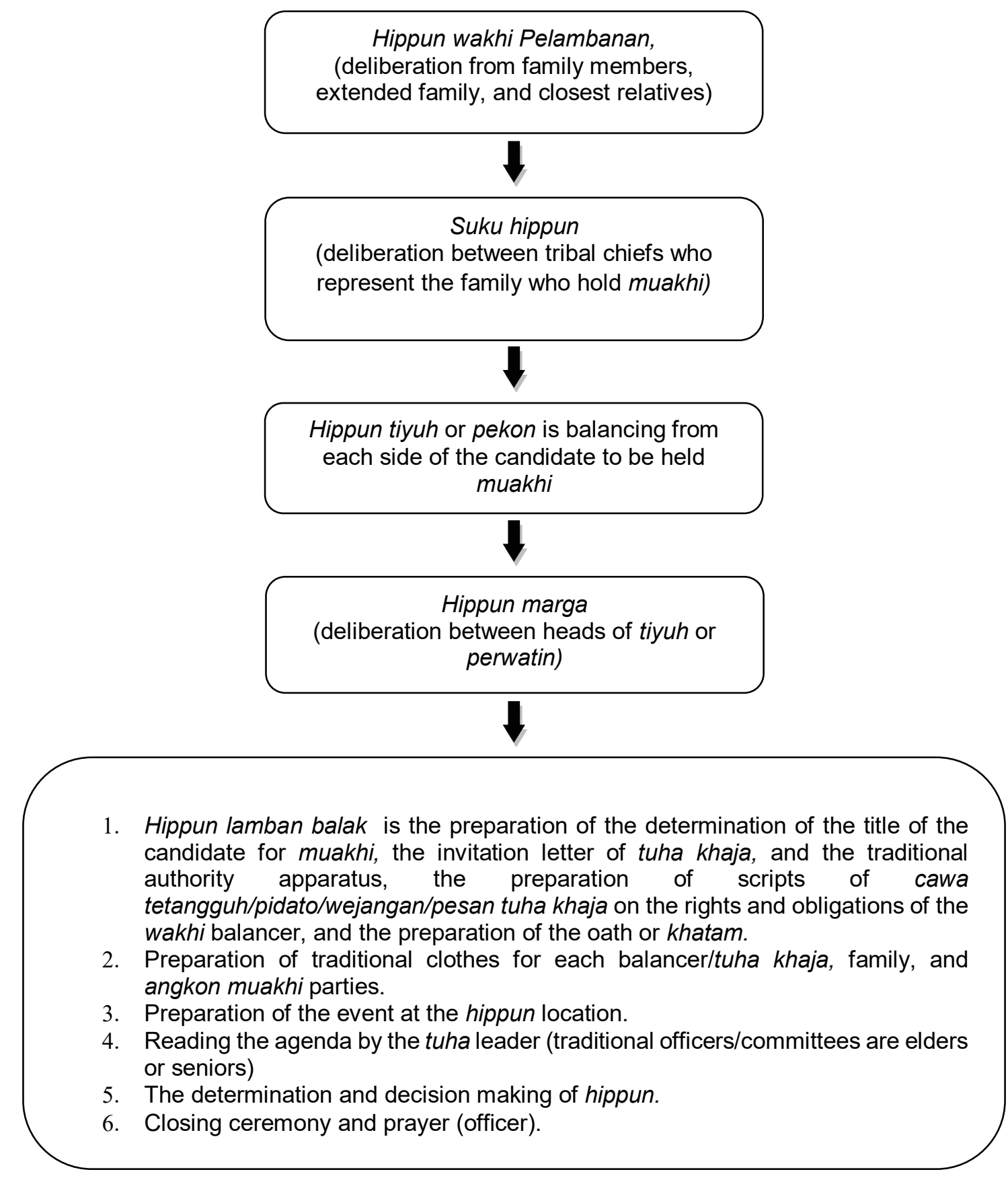

Figure 1.

The steps of the process of angkon muakhi as a traditional ceremony Source: Hartoyo (2019) 
Based on Figure 1, the steps of the process of angkon muakhi as a traditional ceremony are not simple. The process of angkon muakhi begins with family deliberation or what is called hippun muakhi pelambanan. In this process, deliberation is only carried out by the family. Furthermore, after the family deliberation is carried out, each tribal chief representative of the family conducts a deliberation or what is called hippun suku. After conducting the hippun suku, each party who will be muakhi is brought together to conduct deliberation or is called hippun tiyuh. After the hippun tiyuh is carried out, each head of perwatin or head of tiyuh conducts a deliberation called the hippun marga. Each of the hippun marga that holds the deliberations are met at the location for the appointment of the muakhi called hippun lamban balak. Next, the hippun lamban balak becomes the place for the awarding of titles which is attended by the invited guest of tuha khaja, the traditional government apparatus. The place for the hippun lamban is used to carry out the preparation of the scripts of cawa tetangguh/pidato/wejangan/pesan tuha khaja regarding the rights and obligations of the muakhi balancer, and the preparation of the oath or khatam as well as the preparation of traditional clothes for each of the balancer/tuha khaja, the family, and the parties of angkon muakhi. After the preparation for the lamban balak event is completed, the hippun is carried out and it is followed by reading the agenda by the tuha leader and the determination of the hippun decision, as well as closing ceremony and prayer after the event procession is over.

The angkon muakhi procession aims to bind the ties of brotherhood and is a step in realizing mutual agreement in the form of a traditional ceremony process. The purpose of angkon muakhi is as a kinship that is bound by mutually agreed upon agreements during the deliberation, which will later form a kinship like a sibling relationship (Sarbini \& Khalik 2010).

Ethnic conflicts in Lampung in a decade in 2011-2020 had raised conflicts on the surface approximately 20 times, meaning that there is a problem that has not been resolved fundamentally. Most of the ethnic conflicts in Lampung were triggered by trivial things that brought up ethnic issues. For example, in South Lampung, there was a misunderstanding between young men from Bali and Lampung. Meanwhile, a conflict in Central Lampung stemmed from one of the local ethnic groups who stole 3 cows belonging to the residents of Kesumadadi Village who were judged by the local residents to death. This problem triggered the local ethnic group to attack Kesumadadi Village because they carried out a unilateral judge which caused a dispute so that 6 residents' houses were burned and 31 houses were damaged. The conflict in East Lampung stemmed from two young men from Jabung Village committing a robbery in Pematang Tahalo Village who were judged by the residents to death. This problem led to similar consequences as in Central Lampung. Due to the disappointment of one ethnic group with the unilateral judgment, it caused a quarrel that damaged the Pematang Tahalo Village facilities (Prayitno 2019). This inter-ethnic conflict is a social problem that needs to be studied in depth. Meanwhile, Lampung has local wisdom called muakhi as social control. If implemented properly, muakhi can raise brotherly peace.

As a comparison as well as to search for updates, this study looked at references to previous studies that discuss muakhi. A study written by Idrus Ruslan on the dimensions of local wisdom of the Lampung society as a media for conflict resolution to anticipate and resolve conflicts in Lampung used local wisdom and noble values from piil pesenggiri and muakhi (Ruslan 2018). The results of this study showed that local wisdom is an informal value or social capital in avoiding horizontal conflicts.

Another study was written by Nurdin (2009) who discussed muakhi culture and regional development from the perspective of the social philosophy of the Pubian indigenous people in Lampung. Nurdin's study explained about muakhi or brotherhood that contributes socially to regional development because the value of muakhi implies social ethics in the lives of the society in the form of peace. This study was used as a basis for thinking because there were similarities in realizing peace. However, this study focused on muakhi in managing ethnic conflicts to realize brotherly peace.

In his writings, Hartoyo explained muakhi (brotherhood) and its practice to prevent communal conflict in a multicultural society. This writing contained efforts to prevent conflict and restore relations between communities after communal conflicts by means of a socio-cultural approach by applying the values 
of local muakhi policies on the basis of mutual agreement (Hartoyo 2019). The results of this study showed muakhi as local wisdom that can be accepted by ethnic migrants and its implementation as a reinforcement of moral values and socio-cultural ties in maintaining inter-ethnic relations. However, this study examined muakhi in conflict management from the conflict period to the post-conflict period because ethnic conflicts in Lampung still often arise. Therefore, this study aimed to explain muakhi as conflict management from pre-conflict to post-conflict.

Ethnic conflicts in Lampung are developed from problems in the past that have not been resolved to transnormative, even though Lampung has local wisdom in resolving ethnic conflicts. When viewed from previous studies, many have discussed the local wisdom of Lampung in resolving inter-ethnic conflicts, but these studies have not answered about conflict management systems. Therefore, this study offered local wisdom, particularly muakhi culture, in managing inter-ethnic conflicts both from preconflict and post-conflict.

\section{Research Methods}

This study used qualitative research methods to explore, understand, and analyze ethnic conflicts (Creswell 2012). This qualitative study used a phenomenological approach with multiple cases to explain the concept of phenomena based on experience based on individuals in natural situations (Sugiyono 2016). Besides, multiple cases are a study to discuss specific case studies in understanding the issue well. This approach develops and refines existing theories by comparing the cases/problems under study. This approach pays attention in explanatory case studies because the research question refers to the question word 'how' (Putra 2013).

The research site of this study was in the Lampung area because Lampung is commonly known as the Porch of Sumatera Island which is located at the southern tip of Sumatera Island which has its uniqueness and characteristics, where various ethnic groups live in this area. The various kinds of ethnic groups cannot be separated from the transmigration program that forms a multicultural society. Unexpectedly, this transmigration program triggers the emergence of conflicts because the understanding of cultural acculturation between ethnic groups is still low. The Lampung society has a legal structure that is used as a guide to life called piil pesenggiri which means about social order in implementing respect in valuing the community (Ruslan 2018). Piil pesenggiri is the foundation of muakhi which both bring about peace as the form of muakhi is the meaning of piil pesenggiri.

The data were obtained from primary and secondary data by in-depth interviews with research subjects (Kriyantono 2014). The criteria for informants in this study included: 1) The informants are willing to provide information about muakhi culture as conflict management, 2) The informants mastered the topic of conflicts that occurred in Lampung, and 3) The informants are actively involved in handling conflicts in Lampung.

Based on these criteria, the researchers selected four informants who were considered to meet the criteria, including an academic, cultural observer, village officer, and local government. The primary data source was obtained directly from research subjects by means of face-to-face in-depth interviews and documentation that is used to test and examine a phenomenon. The source of documentation in this study was obtained from government regulations in dealing with ethnic conflicts. The secondary data source was obtained from internet media, related research journals, and supporting books (Moleong 2015). The results of in-depth interviews were then analyzed through the transcription process, after which the transcripts were categorized to obtain answers from the interview guidelines. To draw a conclusion, this study analyzed the in-depth interview data, compared to previous studies and the theories studied. 


\section{Results and Discussion}

\section{Muakhi culture in the Lampung ethnic community}

Muakhi is conceptually derived from Arabic which means brotherhood which comes from the word akhun. Etymologically, muakhi culture is very close to religious traditions which have the meaning of brotherhood (Nurdin 2009). Muakhi has many variants that come from the word puakhi which means siblings of the mother or father. Muakhi is a social ethic in society, both morally and religiously, which contains the values of social integration within groups or between groups which are actualized in the relationship of social behavior as shared awareness. Mukahi is a symbol and social capital of the community which is used as an identity and an adaptation both culturally and structurally (Nurdin 2019).

\footnotetext{
"Muakhi, in that sense, means family or brotherhood. So, then, muakhi is formed once the population is large. There is a muakhi that has a connection with blood relations, there is a muakhi that is related to the relationship with a traditional government, there is a muakhi that is related to relatives who are not closed anymore, so they are called muakhi mianak" (informant BUD, traditional leader in Lampung)
}

Muakhi as cultural values and norms functioned as a medium and a forum to adapt to the social environment which aims to create peace in the lives of the society (Qurun \& Dudha 2020). Muakhi culture as the local wisdom of the Lampung indigenous people is a social ethic and social peace that needs to be developed in inter-ethnic relations because Lampung is the first area used in the transmigration program (Levang 2003). Transmigration has created a multicultural society that makes it easier for conflicts to arise. Thus, muakhi culture as local wisdom needs to be developed to prevent and create social peace in Lampung Province.

\footnotetext{
"Muakhi, in Lampung language, there is one thing called angkon muakhi, which means brother, to be a brother. In the past, when there was a conflict between villages, it was discussed in a family way. So, muakhi is the brother. So, they came to the traditional deliberation house, carried out thanksgiving, they slaughtered buffalos in the past. Both the perpetrators and opponents of the conflict, all of them, including traditional leaders and families, were invited to discuss the matter. Both were aware of their actions, forgiving each other, so that they became brothers. Thus, the meaning of muakhi is brotherhood. Brothers are not only from the lineage, but well, brother is brother, when there is a marriage, wedding ceremony, they will be invited, when they are in trouble, they will have a mutual cooperation. When they become brothers, the muakhi is ready to become one unit of a brother. Anything happens, they will be ready for mutual cooperation" (informant JEN, member of DPRD of South Lampung)
}

Muakhi means brotherhood, while to create brotherhood in the Lampung language is called angkon muakhi. In Fauzi Nurdin's study, muakhi is defined as a brotherhood. The Lampung society makes muakhi as a guideline or direction in carrying out social life. The formation of muakhi is a brotherhood that has a procession in a form of the traditional ceremony called angkon muakhi. When the angkon muakhi process has been formed, family values will be established or form a unity, which is mutual cooperation in realizing the value of peace. In creating brotherhood, the angkon muakhi procession is carried out through family deliberation agreed between the conflicting parties that is presented with the slaughter of a buffalo as gratitude. When they become muakhi, there are no longer any boundaries because they have become one unit, helping each other, and working together (Nurdin 2009).

Muakhi culture as stated by Hartoyo is a brotherhood as a form of peace with different perspectives. However, this study shows that muakhi is a brotherhood that has many variants contained in the local wisdom of piil pesenggiri, which is the value of brotherhood which is the meaning of piil pesenggiri as a guide to the life of the Lampung society. This has a purpose as an order for the Lampung society to live harmoniously and side by side in one unit to form brotherly values in the family, neighborly relations, and inter-ethnic relations. If it is seen from Hartoyo's study on muakhi and its practice that is neutral, 
which does not prioritize the value of one ethnic group, so muakhi can be used by various ethnic groups in the Lampung area (Hartoyo 2019).

Local wisdom as conflict resolution is an effective form of peace because it recognizes the conditions of the region and local culture. This encourages latent conflicts to be resolved quickly and easily accepted by the people in conflict. By referring to Hendry Bakri's study which discussed conflict resolution through the local wisdom approach of pela gandong in Ambon City, it can be seen that this study explained that pela gandong is a covenant bond of different religions based on blood relations between the descendants of the Poso community and the Batu Merah community. The bond of the pela gandong agreement is a form of reconciliation that can restore strong friendly relations (Bakri 2015). However, this study described muakhi as a brotherhood that has many variants, either brotherhood from sibling, family, neighborly relations, and inter-ethnic relations, in which the practice and nature are neutral. Lampung is a multicultural area that is easy to get into conflicts and differences. Therefore, the local wisdom of muakhi culture is neutral which can be accepted by all elements of society in Lampung as a form of one regional brotherhood. These two studies described conflict resolution using local wisdom with different processes.

\section{Conflict management in the Lampung ethnic community}

Conflict management theory explains that the conflict does not have to be solved by solving problems, but it can be a lesson on how to manage conflict to reduce the escalation of violence, meaning that conflict management is a strategic practice in each party, both the conflicting party and the mediator (Susan 2011). Conflict management aims to control and manage, organize, and regulate in reducing conflict productively. This understanding explains to keep conflict away from all forms of violence to create a balance in conflict (Susan 2009). Conflict management is defined as preserving the conflict area from conflicts and disputes in violence, which means conflict management efforts through a conflict resolution process with the tools of power and authority (Setiyani 2016). This perspective has three keywords in conflict management, including power, authority, and peace as opposed to violence (Taufik 2018).

Table 1.

Conflict management style

\begin{tabular}{|c|c|c|}
\hline \multicolumn{2}{|r|}{$\begin{array}{c}\text { Conflict } \\
\text { management style }\end{array}$} & Conflict management techniques \\
\hline 1. & Competing & $\begin{array}{l}\text { Competing is a conflict approach that sees a fight from win-lose approach. } \\
\text { For example, Lampung and Bali get involved in a competition to fight for their } \\
\text { interests by harming the interests of others with the aim of getting what they } \\
\text { are fighting for by defeating the other party. }\end{array}$ \\
\hline 2. & Collaborating & $\begin{array}{l}\text { Collaborating is a conflict approach in which two conflicting parties } \\
\text { collaborating to find a conflict resolution to get satisfaction in interests. } \\
\text { Conflict management using collaborative techniques is a win-win approach } \\
\text { that aims to get what they want for all parties. }\end{array}$ \\
\hline 3. & Compromising & $\begin{array}{l}\text { Compromising is a technique in conflict resolution where both parties give } \\
\text { each other concessions. Both work together to resolve the conflict without } \\
\text { harming the interests of the organization. This approach gives satisfaction } \\
\text { to both parties involved in the conflict because there is no winner or loser. }\end{array}$ \\
\hline & Avoiding & $\begin{array}{l}\text { Avoiding is a technique that is not cooperative and not assertive. Avoiding } \\
\text { or withdrawing from something that develops that is neutral is an ability to } \\
\text { balance problems so as not to cause prolonged conflict. }\end{array}$ \\
\hline & Accommodating & $\begin{array}{l}\text { Accommodating approach is obtained from the parties involved in the } \\
\text { conflict because one party has let go or put aside the interests of the group } \\
\text { and prioritizes the interests of the other party. This is a win-lose approach } \\
\text { because one party has given their wish to the other party or has given up } \\
\text { their desire to the other party to get a complete will. }\end{array}$ \\
\hline
\end{tabular}

Source: Wirawan (2018) 
Thomas Kilmann and Ralph H. Kilmann have developed a conflict management style through two understandings, consisting of cooperation on the horizontal axis and assertiveness on the vertical axis. This means that cooperation is an effort to meet the needs of one's own party and other parties in dealing with conflict, while assertiveness is an attempt to meet one's own needs in dealing with conflict (Rusdiana 2019). Management requires the parties involved in the conflict to be able to develop conflict strategies and implement them with the aim of getting the desired resolution (Rahma \& Lestari 2020). Thomas and Kilman proposed five styles in managing conflict, including competing, collaborating, compromising, avoiding, and accommodating. The following five styles and techniques of conflict management in Lampung are presented in Table 1.

Table 1 illustrates that to measure ethnic conflict management style in Lampung, this study used Thomas and Kilmann's theory as an effort to meet the needs of self and other parties when encountering horizontal conflicts. Conflict management styles can be carried out in five stages, including competing, collaborating, compromising, avoiding, and accommodating. In resolving ethnic conflicts in Lampung, the parties involved in the conflict need skills to carry out conflict management. As stated by Syufa'at et al. (2017) in their study discussing the religious and cultural movement of the community called sekelik sedulur, in preventing inter-ethnic conflict in Central Lampung, it shows an element of cooperation between ethnic communities and local wisdom in building inter-ethnic harmony.

Hendry Bakri (2015) also explained conflict resolution using a more efficient local wisdom method with various perspectives. Unexpectedly, the formation of ethnic conflicts in Lampung is developed due to the transmigration program, which made the Lampung area multicultural and it formed enclaves in which the population is in groups, resulting in less integration. This issue triggers the emergence of horizontal conflict. Therefore, this study used the theory of conflict management style as an answer to conflict resolution. This theory focuses on the solution and the completion process which is depicted in Figure 2.

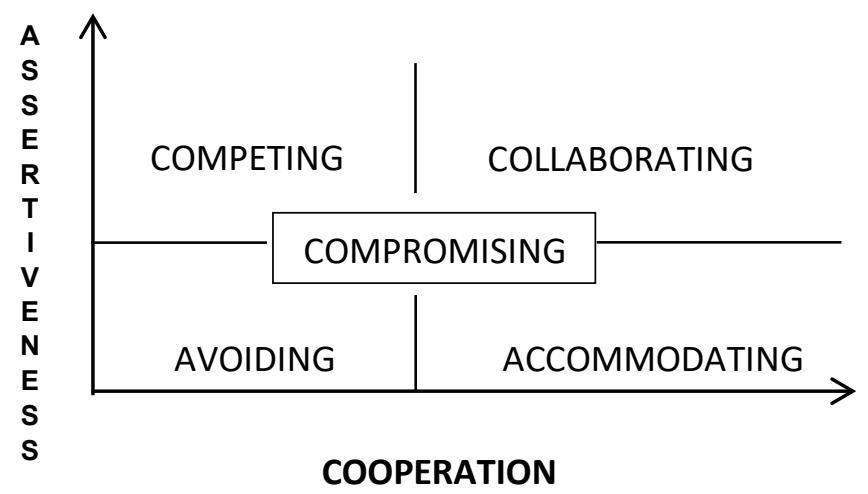

Figure 2.

Conflict management style framework Source: Wirawan (2018)

\section{Muakhi as conflict management}

Muakhi can be understood as a brotherhood that is manifested in the form of inter-ethnic relations. In resolving inter-ethnic conflicts, muakhi cannot be separated from the appointment of brotherhood. As a matter of fact, the migrant community has accepted the ties of brotherhood even though they do not understand the meaning of muakhi, and the migrant community with the local people have implemented the practice of muakhi in their daily life. The practice of muakhi has formed a brotherhood both in working, studying, and neighboring relationships.

"Muakhi, in dealing with inter-ethnic conflicts, is muakhi related to the relationship of the traditional government. So, the lowest rank community is ngabihi, in which ngabihi oversees 10 heads of 
families under the neighborhood unit, while for ngabihi, every four ngabihi appoints a person from the rank of temenggung. Likewise, for temanggung, every four emanggung will also appoint kariya, then the kariya also appoints a pangiran, and then the pangiran also appoints khatu" (informant BUD, traditional leader in Lampung).

The traditional leader in Lampung said that ngabihi is a term for people who occupy the lowest traditional government positions in charge of 10 heads of families as a control in their area. Meanwhile, the temanggung is a traditional government position above the ngabihi which oversees four ngabihi or 40 heads of families. The four temenggung have the right to appoint a kariya as their leader who oversees 160 heads of families. Then the four kariya appoint a pengiran as head of the kariya leader. Likewise, the four pengiran appoints a khatu as their leader.

\begin{abstract}
"Muakhi here is related to the traditional government. If a clash between ngabihi and ngabihi cannot be resolved by the ngabihi, it will be resolved by the elder temenggung. Then, if it cannot be resolved under the control of temenggung, if it is still in conflict, it still cannot be resolved, then it will be resolved by someone with the rank of kariya. Likewise, between one neighborhood unit and another, the person who handles it is the head of hamlet. If it still cannot be resolved by the head of hamlet, it will be handled by the village head. So, in relation to muakhi, if one has been appointed as a relative, then the one who will handle the problem is those who raise as the family. For example, Balinese people are appointed by Lampung people, appointed by a temenggung. If the two are in conflict, then the temenggung has to resolve the conflict." (informant BUD, traditional leader in Lampung).

"Muakhi, in dealing with the conflict, allows us to consult with traditional leaders. These figures give advice, act as mediators, while now, there are security forces who mediate. Traditional leaders from Lampung give their voice, traditional leaders from Bali give their voice, then there is a deliberation. So, in the process of this deliberation, there is an elder, so that people will listen to them, those who give their voice are role models" (informant JEN, member of DPRD of South Lampung).
\end{abstract}

In dealing with ethnic conflicts, muakhi always consults with high-ranking traditional leaders to conduct deliberations from Lampung traditional leaders with Balinese traditional leaders, which are carried out by their traditional leaders or elders, so that they can be accepted by each group. This brotherly procession is facilitated and mediated by the security forces with the aim of obtaining a peaceful agreement.

Muakhi, in conflict management in Lampung, aims to prevent violence in conflict through management that is used as conflict transformation (Miall 2004). Muakhi is local wisdom that is used as conflict management in Lampung. Muakhi, in conflict management in Lampung, has several styles in dealing with conflict, including: first, competing for win-lose. Second, muakhi in dealing with conflict collaborate to find conflict resolutions to get satisfaction in interests. Third, compromising to create integration between conflicting parties that provides concessions. Fourth, one of the parties avoids as an effort to balance the problem so as not to cause a prolonged conflict. Fifth, accommodating is an effort to stop the conflict because one party has given their interest to the other party or has given up their interest to the other party to get a complete will. "Muakhi, in managing conflict here is an early alert system, a warning system or an early response system and an early answer system" (informant HAR, academic).

This study found that muakhi in the conflict management system is still weak because it is not formulated in its own system to anticipate the occurrence of latent conflicts that will develop into manifest conflicts. This kind of understanding by the security forces has not yet been considered as a conflict because it has not created violence. Therefore, there is a need for a redefinition of latent conflict with manifest conflict, which is how to manage latent conflict that is well managed until it creates productive competition. This conflict is then managed to create a constructive and productive pluralism in the life of the community. Therefore, muakhi is the concept of an early response system and an early answer system. This means that muakhi is not only conflict resolution but also the anticipation of inter-tribal conflict. On this basis, the concept of muakhi thus needs to be promoted and actualized in activities involving various ethnic groups. 
Ethnic conflict management has created muakhi practices where conflict management in South Lampung has created a warning system that cooperates with each other in maintaining well-managed latent conflicts to create constructive and productive pluralism so as not to create manifest conflicts in the governance of the lives of the society. Cooperation has involved all elements, both from the government and traditional leaders who are used as social control. This means that muakhi as ethnic conflict management in Lampung aims to create brotherly peace in a systematic way to know the practices of muakhi (Wirawan 2018). Muakhi practices in managing ethnic conflict in Lampung use the theory of Thomas Kilmann and Ralph H. Kilmann who have developed a conflict management style through two understandings, including cooperation on the horizontal axis and assertiveness on the vertical axis. This means that this cooperation is an attempt to meet the needs of the parties themselves and other parties in dealing with conflicts, while assertiveness is an attempt to meet their own needs in dealing with conflicts (Rusdiana 2019).

\begin{abstract}
"Making an agreement to remind each other that if there is a conflict, they are not the ones who resolve it. For example, one village secretary calls another village secretary. Let's say there is an Agom resident watching the organ. The one there will immediately call me. I immediately ask who the Agom resident visiting Balinuraga is to watch the organ. For example, this one. I immediately call the resident, don't do various things there and vice versa from the Balinuraga, meaning we are side by side, in fact, we are more familiar now" (informant RUD, Agom Village apparatus).
\end{abstract}

In practice, in resolving conflicts, there is an element of cooperation in muakhi, reminding each other that if there are parties from Bali or Lampung who play in their area, each region reminds each other so as not to cause problems. Thus, on the basis of this mutual reminding cooperation, it creates peace because the government officers provide facilitators to achieve mutual harmony. This is in line with the research conducted by Ferdian which discussed conflict resolution in the Mesuji 45 register area which explained that the handling of conflicts in Mesuji Lampung was carried out by means of mediation or meetings by presenting third parties to make collaborations as peace efforts (Ferdian 2017). This shows that in an effort to resolve conflicts, cooperation between parties is required. Thomas and Killman stated that conflict management is formed from cooperation on the horizontal axis (Rusdiana, 2019). Cooperation is an attempt to meet the needs of one's own party and the other party in dealing with conflict. A study conducted by Saputro Prayitno on the topic of handling social conflicts in South Lampung (a study on the Lampung Regional Police) due to clashes between Balinuraga Village and Agom Village showed that the cause of the conflict was the lack of communication between ethnic communities (Prayitno 2019). This study stated that post-conflict recovery efforts need to be handled by the government, traditional leaders, and religious leaders together. This indicated that all parties must work together to achieve peace as the people of South Lampung have done, which was through reconstruction and rehabilitation efforts to carry out post-conflict recovery.

Thomas and Killman in conflict management have five conflict management styles including competing, collaborating, compromising, avoiding, and accommodating. These five styles are reflected in the resolution of ethnic conflicts in Lampung using local wisdom, particularly the muakhi culture. Creating a muakhi brotherhood has several processions, including: a competition to win-lose, when ones get what they want, they will collaborate, which is guided by the highest head to get satisfaction in interests, after collaborating and compromising, both parties give each other concession that causes both parties to the conflict to get mutual satisfaction that does not harm either party. Then, it is managed, regulated, and handled well. After that, this conflict will create brotherly peace.

Muakhi in conflict management has been controlled by a third party as a form of transformational peace. According to John Paul Laderbach, in realizing peace in a transformational way, a conflict management approach must be used because conflict management as a controller and manager is carried out by the third party (Ghozali 2020). Muakhi in realizing peace in a brotherly manner is carried out by managing conflict which is managed with elements of cooperation from the conflicting parties and controlled by all elements of society, both from village officers, traditional leaders, community leaders, religious leaders, or community organizations. 


\section{Conclusion}

Muakhi as the ethnic conflict management in Lampung creates brotherly peace. First, in creating brotherhood, pre-conflict has some processions, including: a competition to win-lose, when ones get what they want, they will collaborate, which is guided by the highest head. After the collaboration is carried out, then compromising or customary deliberation from both parties is carried out. They will give each other concessions to get mutual satisfaction and make an agreement that does not harm either party. Second, creating a post-conflict brotherhood. It involves related parties, both village officers, traditional leaders, religious leaders, or all elements reminding each other with elements of cooperation, coexistence, and being given insight by village officers about national insight so that the community can understand their mistakes. This study concluded that muakhi in conflict management is managed and controlled by all elements of society, whether from village officers, traditional leaders, religious leaders, community leaders, or community organizations who remind each other, by means of collaboration between conflicting parties to create social and media integration and a forum for creating peace in accordance with the values and norms in the lives of the community.

\section{References}

Andria RD (2019) Transmigrasi masa doeloe kini dan harapan kedepan. [Accessed 26 July 2021]. https://disnakermobduk.acehprov.go.id/index.php/jelajah/read/2019/02/07/7/transmigrasi-masadoeloe-kini-dan-harapan-kedepan.html.

Bakri H (2015) Resolusi konflik melalui pendekatan kearifan lokal pela gandong di Kota Ambon. Jurnal Magister Ilmu Politik 1 (1):51-60.

Budianto A (2020) Ketegangan sosial di Lampung akibat program transmigrasi di era 1950an. Jurnal Candi 20 (1):18-31.

Creswell JW (2012) Research Design, Pendekatan Kualitatif, Kuantitatif dan Mixied. Jakarta: Pustaka Pelajar.

Ferdian JK (2017) Model resolusi konflik kawasan register 45 Mesuji Lampung berbasis hutan tanaman rakyat. Politika: Jurnal Ilmu Politik 8 (1):92-102. https://doi.org/10.14710/ politika.8.1.2017.92-102.

Ghozali AM (2020) The concept of conflict management in the medina charter. Atlantis Press 492 (RIICMuSSS 2019):58-263. https://doi.org/10.2991/assehr.k.201113.049.

Hartoyo (2019) Muakhi (brotherhood) and its practices related to preventing communal conflict in multicultural societies. Masyarakat, Kebudayaan dan Politik 32 (3):227-239.

Irham A (2013) Kebijakan politik multikultural dan upaya mencegah konflik sosial berbau sara: Belajar kasus Waypanji Lampung Selatan. TAPIs 9 (1):1-15.

Khoiriyah F, Fahri A, Bramantio B, \& Sumargono S (2019) Sejarah toponimi daerah transmigrasi Provinsi Lampung melalui tuturan tradisi lisan. Agastya: Jurnal Sejarah dan Pembelajarannya 9 (2):221-240. https://doi.org/10.25273/ajsp.v9i2.4419.

Kriyantono R (2014) Teknik Praktis Riset Komunikasi. Jakarta: Kencana Prenadamedia.

Levang P (2003) Ayo ke Tanah Sabrang. Jakarta: KPG (Kepustakaan Populer Gramedia).

Miall H (2004) Conflict Transformation: A Multi-Dimensional Task. In: Austin A, Fischer M, \& Ropers N (eds). Transforming Ethnopolitical Conflict. VS Verlag für Sozialwissenschaften Wiesbaden. https://doi.org/10.1007/978-3-663-05642-3 4.

Minandar CA (2019) Aktualisasi piil pesenggiri sebagai falsafah hidup mahasiswa Lampung di tanah rantau. Sosietas 8 (2):517-526. https://doi.org/10.17509/sosietas.v8i2.14594.

Moleong LJ (2015) Metodologi Penelitian Kualitatif. Jakarta: Remadja Karya.

Nurdin AF (2009) Budaya Muakhi. Jakarta: Gama Media.

Nurdin AF (2009) Budaya muakhi dan pembangunan daerah menuju masyarakat bermartabat. Jakarta: Gama Media.

Nurdin AF (2019) Integralisme Islam dan kontribusi budaya muakhi bagi peradaban masyarakat serta relevansi nilai-nilai filosofis budaya lokal dan pembangunan masyarakat Lampung. Al-Adyan 14 (1):35-50. https://doi.org/https://doi.org/10.24042/ajsla.v14i1.4481. 
Nurdin BV (2017) Nemui Nyimah: Kearifan lokal untuk pembangunan toleransi yang berkualitas. Aura $1(1): 81-90)$.

Pratiwi D \& Insani M (2019) Bagelen desa transmigrasi pasca reformasi di Lampung. Seminar Nasional Sejarah ke 4 Jurusan Pendidikan Sejarah Universitas Negeri Padang 374-383. https://doi.org/ https://doi.org/10.31227/osf.io/kmgy3.

Prayitno S (2019) Penanganan pasca konflik sosial di Lampung Selatan (studi pada wilayah Polda Lampung). Cepalo 3 (1):35-40. https://doi.org/10.25041/cepalo.v3no1.1788.

Putra MGBA (2013) Peran kearifan lokal dalam resolusi konflik keyakinan beragama di Jawa Timur. Masyarakat, Kebudayaan dan Politik 26 (1):1-14.

Qurun KA \& Dudha LPR (2020) Filosofi budaya muakhi perspektif Fauzie Nurdin. Indonesian Journal of Islamic Theology and Philosophy 2 (2):121-136. https://doi.org/https://doi.org/10.24042/ijitp. v2i2.6998.

Rahma MA \& Lestari SB (2020) Manajemen konflik organisasi untuk menjaga komitmen dalam Unit Kegiatan Selam 387 Universitas Diponegoro. Interaksi Online 8 (1):202-232.

Rusdiana (2019) Manajemen Konflik. Jakarta: Pustaka Setia.

Ruslan I (2018) Dimensi kearifan lokal masyarakat Lampung sebagai media resolusi konflik. Kalam 12 (1):105-126. https://doi.org/10.24042/klm.v12i1.2347.

Singagerda SF, Alfian F, Sari N, \& Akbar MF (2020) Islamic integralism and muakhi culture: The relevance of philosophical values of local culture and Lampung community development. International Journal of Disaster Recovery and Business Continuity 11 (3):1880-1892. http:// sersc.org/journals/index.php/IJDRBC/article/view/33848.

SarbiniA \& Khalik AT (2010) Budaya Lampung Versi Adat Megou Pa' Tulang Bawang. Yogyakarta: Badan Penerbitan Filsafat UGM.

Setiyani W (2016) Tipologi dan tata kelola resolusi konflik di tinjau dari perspektif teori sosial konflik. Teosofi 6 (2):275-299. https://doi.org/https://doi.org/10.15642/teosofi.2016.6.2.275-299.

Sinaga RM (2017) Revitalisasi Buadaya: Strategi Identitas Etnik Lampungle. Jakarta: Suluh Media.

Sugiyono (2016) Metode Penelitian Kuantitatif, Kualitatif dan R\&D. Bandung: Alfabeta Bandung.

Susan N (2009) Sosiologi Konflik: Teori-teori dan Analisis. Surabaya: Prenada Group.

Susan N (2011) Tata kelola konflik demokrasi: Kasus tata kelola konflik di Aceh. Global Strategis 5 (1):15-31.

Syahputra MC \& Ruslan I (2021) Nemui nyimah: Lampung local wisdom with religious moderation insight. Akademika: Jurnal Pemikiran Islam 26 (1):59-74.

Syufa'at MA, Cahyono H, \& Madku A (2017) Gerakan agama dan budaya komunitas Sekelik Sedulur dalam mencegah konflik etnis di Lampung Tengah. Ri'ayah: Jurnal Sosial dan Keagamaan 2 (1):64-84.

Taufik A (2018) Tata kelola konflik dalam pemilihan kepala desa di Kabupaten Bantaeng. Jurnal Politikom Indonesiana 3 (1):14-25. https://doi.org/10.31227/osf.io/bjruv.

Wirawan (2018) Konflik dan Managemen Konflik. Jakarta: Salemba Humanika. 